\title{
ECONOMIA SOCIAL INCORPORATIVA (e as novas linguagens)
}

\section{Welinton dos Santos ${ }^{1}$ Breslei Max Reis da Fonseca ${ }^{2}$}

Resumo: A inovação tecnológica aliada à interação de comunicação sem limites, chamada de "Economia Social Incorporativa", sendo uma rede integrada e sociável as populações do mundo. Baseada em uma pesquisa bibliográfica de caráter qualitativo e documental mostrando que a comunicação, informações e tecnologias evoluem surgindo novos materiais em destaque o grafeno, composto por átomos de carbono com alta condutividade térmica e elétrica, flexível e resistente, material que pode substituir o silício e permitir a segunda revolução tecnológica e levando consigo a economia. Com esses feitos tecnológicos a humanidade tende a estar mais do que nunca com uma ligação inseparável das novas tecnologias que vem aparecendo de forma exponencial no mercado estimulando assim mais do que nunca a economia social. 0 futuro visa uma nova economia que está em transformação, provocando mudanças significativas na política econômica mundial, e por isso, todos os esforços nesta nova dinâmica de conscientização do comportamento social integrativo auxilia numa política estratégica global mais justa e igualitária.

Palavras-chave: Economia; Redes sociais; Economia social incorporativa.

\footnotetext{
${ }^{1}$ Engenharia/ETEP Faculdades, Brasil. E-mail: Welinton.economista@gmail.com.

2 Engenharia/ETEP Faculdades, Brasil. E-mail: bresleimax@rocketmail.com.
} 